\title{
Communal or competitive? Stable isotope analysis provides evidence of resource partitioning within a communal shark nursery
}

\author{
Michael J. Kinney ${ }^{1, *}$, Nigel E. Hussey ${ }^{2}$, Aaron T. Fisk ${ }^{2}$, Andrew J. Tobin ${ }^{1}$, \\ Colin A. Simpfendorfer ${ }^{1}$ \\ ${ }^{1}$ Fishing and Fisheries Research Centre, School of Earth and Environmental Sciences, James Cook University, Townsville, \\ Queensland 4811, Australia \\ ${ }^{2}$ Great Lakes Institute for Environmental Science, University of Windsor, 401 Sunset Avenue, Windsor, Ontario N9B 3P4, \\ Canada
}

\begin{abstract}
Quantifying the diet of sympatric co-occurring predatory species is a challenging task, made more so when investigations attempt to focus on specific age groups. This is the task that confronts efforts to understand dietary resource partitioning among co-occurring juvenile shark species within nursery areas. Here, stable isotope analysis $\left(\delta^{13} \mathrm{C}\right.$ and $\left.\delta^{15} \mathrm{~N}\right)$ is used to overcome these challenges in describing species dietary resource partitioning strategies within the communal shark nursery area of Cleveland Bay, Queensland, Australia. We analyzed the isotopic composition of 3 distinct tissues, (muscle, blood plasma, and red blood cells), for 7 species of shark and 3 species of large predatory teleost to investigate whether these communal areas support their diverse array of predators without the need for resource partitioning strategies. Clustered $\delta^{15} \mathrm{~N}$ values for all examined species indicated feeding within the same trophic level; however, wide ranging $\delta^{13} \mathrm{C}$ values denoted exploitation of several primary carbon sources. Our results demonstrate inter-species resource partitioning strategies at work within the examined communal shark nursery, altering the previous interpretation of these areas as resource-rich and/or competitionlimited environments.
\end{abstract}

KEY WORDS: Coastal $\cdot$ Dietary overlap $\cdot$ Muscle $\cdot$ Niche partitioning $\cdot$ Plasma $\cdot$ Red blood cells Resale or republication not permitted without written consent of the publisher

\section{INTRODUCTION}

The use of discrete inshore shallow water areas as nurseries by juvenile sharks has been established in the scientific literature since the mid twentieth century (Springer 1967). Over time many aspects of the original shark nursery area theory have been altered, omitted, or added to, but the central paradigm has persisted. One of the longest standing tenets of the nursery area paradigm is the theory of resource abundance - the idea that young sharks can remain in the nursery while feeding and growing for the first few years of life with little to no competition (Branstetter 1990, Salini et al. 1992, Castro 1993, Simpfendorfer \& Milward 1993).

More recent shark nursery area studies are finding evidence countering the theory of nursery area resource abundance. Evidence of slow growth rates (Bush \& Holland 2002, Lowe 2002, Duncan \& Holland 2006) and high mortality rates of young sharks in nursery areas has been attributed in part to a lack of sufficient food resources (Manire \& Gruber 1993, Duncan \& Holland 2006). In the Gulf of Mexico, mortality rates of up to $90 \%$ for juvenile blacktip sharks 
Carcharhinus limbatus within Terra Ceia Bay, Florida, USA, were attributed to natural mortality, including predation, starvation, and disease (Heupel \& Simpfendorfer 2002). These findings provide strong evidence that the view of nursery areas as protective, resource abundant reserves for young sharks is outdated and no longer fits much of the current data (Heupel et al. 2007).

While evidence of resource limitations within single species nursery areas is mounting, few studies have investigated resource partitioning among cooccurring shark species (Salini et al. 1992, Platell et al. 1998, Bethea et al. 2004, White et al. 2004), with only Bethea et al. (2004) focusing specifically on juveniles in these areas. Although these studies have found some evidence of resource partitioning, several limitations inherent to stomach content analysis have made determining broad-scale resource partitioning difficult. These include: the snapshot nature of stomach content data (Pinnegar \& Polunin 1999, Pinnegar et al. 2001, Bearhop et al. 2004, MacNeil et al. 2005), the persistence of hard structures like cephalopod beaks and crustacean shells (Wilson et al. 1985) and, in the case of animals such as sharks, the preponderance of empty stomachs and unidentifiable prey items (Cortés 1997). These limitations typically necessitate large sample sizes (Cortés 1997, 1999, Estrada et al. 2005, MacNeil et al. 2005), which however are often feasible either due to simple project logistics or concerns over a species' conservation status (Heupel \& Simpfendorfer 2010). These problems are compounded further when an investigation seeks to understand the diet of a select size or age range, for example the diet of young sharks within nursery areas.

One way to address the limitations of stomach content analysis is through the use of naturally occurring stable isotopes of carbon $\left(\delta^{13} \mathrm{C}\right)$ and nitrogen $\left(\delta^{15} \mathrm{~N}\right)$. This technique has emerged as a powerful alternative or complementary tool for assessing the feeding ecology of organisms (Domi et al. 2005). The approach is based on the principle that the stable isotope ratios in consumer tissues can be related in a predictive way to those in their diet (DeNiro \& Epstein 1978, 1981). Values of $\delta^{13} \mathrm{C}$ can be used to track sources of primary carbon, as $\delta^{13} \mathrm{C}$ shows relatively little change between trophic levels $(\sim 1 \%$ per trophic level) from primary producers up through apex predators (Peterson \& Fry 1987, Hobson \& Welch 1992). As such, $\delta^{13} \mathrm{C}$ can be a useful indicator of sources of primary productivity in simple systems where at least 2 isotopically distinct sources are present (Hobson et al. 1995). Enrichment of ${ }^{15} \mathrm{~N}$ occurs at a rate of approximately 2 to $4 \%$ of $\delta^{15} \mathrm{~N}$ with each step up in trophic level (Peterson \& Fry 1987, Michener \& Schell 1994, Post 2002), making it possible to model an organism's relative trophic position within a given ecosystem.

Stable isotope analysis (SIA) provides many benefits over traditional stomach content analysis: (1) it represents assimilated, not just ingested, prey items (Bearhop et al. 2004, Domi et al. 2005); (2) isotopic values represent long-term feeding behaviours (from months to years depending on the tissue analyzed) (Domi et al. 2005, MacNeil et al. 2005, 2006); (3) sampling multiple tissues can provide distinct timeframes due to differences in tissue turnover rates (Kurle \& Worthy 2002, MacNeil et al. 2005); and (4) samples from several different tissues can be obtained without the need to euthanize animals. SIA therefore provides a useful tool to investigate questions such as dietary resource partitioning within communal shark nursery areas.

While a number of SIA studies have been carried out on the structure of marine food webs (Hobson \& Welch 1992, Michener \& Schell 1994, Hobson et al. 2002), and focusing on specific teleost species (Thomas \& Cahoon 1993, Das et al. 2000, Harvey et al. 2002, Cunjak et al. 2005, Perga \& Gerdeaux 2005, Schlacher et al. 2005), little research has been published on SIA for sharks. These include a handful of field studies that focus on sharks and rays (Fisk et al. 2002, Estrada et al. 2003, Domi et al. 2005, MacNeil et al. 2005, Estrada et al. 2006, Kerr et al. 2006, McMeans et al. 2009), and only 3 laboratory studies: MacNeil et al. (2006), who assessed variable uptake and elimination of carbon and nitrogen isotopes in the tissues of freshwater ocellate river stingrays Potamotrygon motoro; Hussey et al. (2010a), who looked at diet-tissue discrimination factors in large sharks held under semi-controlled conditions; and Logan \& Lutcavage (2010), who investigated the effects of diet switching on captive sandbar sharks Carcharhinus plumbeus.

The present study utilized SIA of multiple tissues representing variable integration periods to assess the extent of dietary resource partitioning by 7 of the most commonly occurring juvenile shark species, as well as 3 large predatory teleost species, within an established communal shark nursery area (Simpfendorfer \& Milward 1993). The juvenile shark species examined were distributed throughout the nursery, displayed varying degrees of spatial and temporal overlap, and rarely left the nursery during early life (M. J. Kinney unpubl. data). Therefore, comparisons of stable isotope values between species were not 
compromized by spatial or temporal factors specific to any one section of the bay. Results from this study will further our understanding of the important ecological interactions at work within communal nursery areas and may assist in the prioritization of conservation and management strategies for co-occurring shark species in nursery environments.

\section{MATERIALS AND METHODS}

\section{Study site}

Cleveland Bay is situated east Townsville on the north-east coast of Queensland, Australia, and covers an area of approximately $225 \mathrm{~km}^{2}$ from $19^{\circ} 10^{\prime}$ to $19^{\circ} 19^{\prime} \mathrm{S}$ and from $146^{\circ} 50^{\prime}$ to $147^{\circ} 01^{\prime} \mathrm{E}$. The bay is shallow throughout, reaching a maximum depth of $15 \mathrm{~m}$ near its outer edge. The benthic environment of the bay is predominantly soft mud with some smaller areas of coastal reefs; for a more detailed analysis of the sediment types in Cleveland Bay see Cruz-Motta \& Collins (2004). Much of the bay is covered in seagrass throughout the year (Grech \& Coles 2010). Sea surface temperatures in the bay fluctuate between $30.5^{\circ} \mathrm{C} \pm 0.5$ during the summer and $22.5^{\circ} \mathrm{C} \pm 0.2$ during the winter (M. J. Kinney unpubl. data). Mangroves dominate the southern shore of the bay as well as the tidal sections of the 4 major waterways providing freshwater inputs into Cleveland Bay: Ross River and Ross Creek to the west, and Crocodile and Alligator Creeks to the south. However, since these waterways contain weirs, they remain brackish during much of the year and only output significant amounts of fresh water when the weirs overflow. This typically occurs during the summer, when outflows from the waterways cause a significant drop in the bay's salinity, from $39 \%$ \% \pm 0.4 in the winter to $36 \% \pm$ 1.6 in the summer (M. J. Kinney unpubl. data).

\section{Field sampling for stable isotope tissues}

Multiple tissue samples were collected from 7 species of sharks and 3 species of teleost inhabiting Cleveland Bay during fisheries-independent sampling trips from November 2008 to May 2010 (Table 1). Although juvenile sharks of other species were caught during sampling, the 7 species investigated here are the most likely species to use Cleveland Bay as a nursery based on their numerical dominance in the catch. Sampled animals were captured using longlines and gillnets deployed throughout the

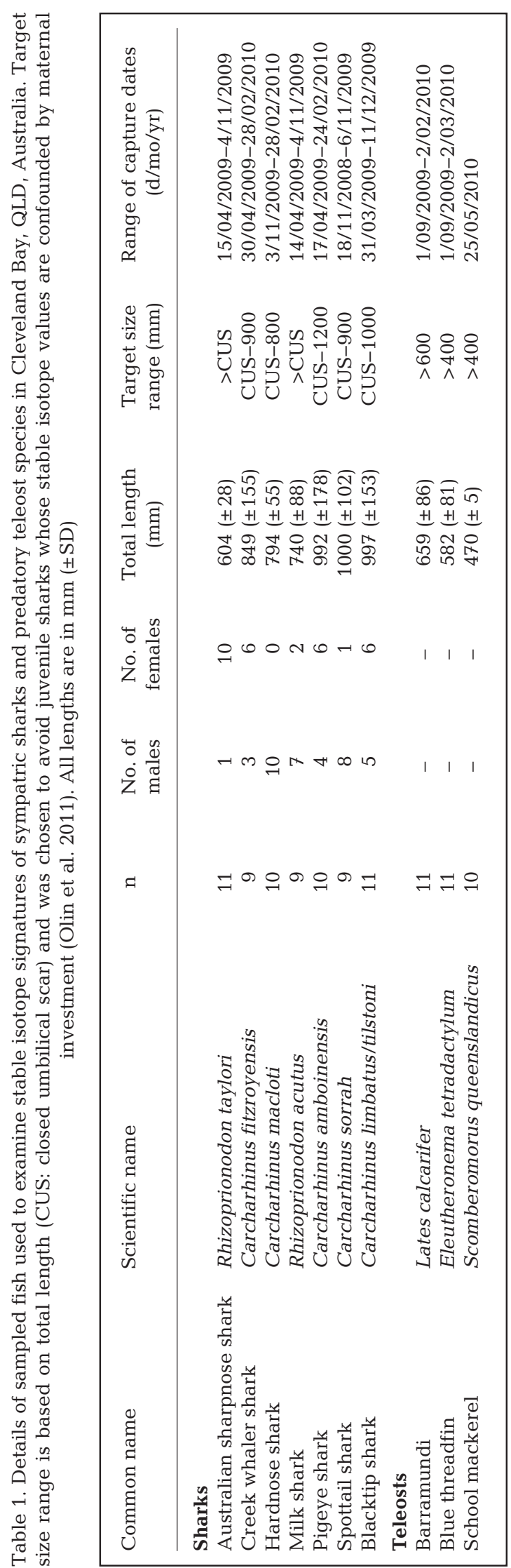


bay. Longlines consisted of an $800 \mathrm{~m}$ main line of $8 \mathrm{~mm}$ diameter nylon rope that was anchored at both ends. Floats were attached to both ends for retrieval of the gear and marker floats were placed every $200 \mathrm{~m}$ along the main line to indicate the line's location. Five $\mathrm{m}$ long gangions were attached to the main line approximately every $10 \mathrm{~m}$. Gangions were constructed from $3.5 \mathrm{~m}$ of $4 \mathrm{~mm}$ diameter polyester rope attached to the main line by a stainless steel 5' shark clip. The polyester rope was then attached to a $1.5 \mathrm{~m}$ long $1.8 \mathrm{~mm}$ diameter nylon coated wire leader by a stainless steel swivel. The wire leader then terminated in either a 14/0 or 16/0 galvanized circle hook which was baited upon deployment. One $300 \mathrm{~m}$ long gillnet constructed of 40 ply monofilament nylon mesh was used. The net was hung on a $6 \mathrm{~mm}$ nylon float line with floats attached every $154 \mathrm{~cm}$; a $140 \mathrm{gm}^{-2}$ lead-core rope was attached to the bottom of the net. The mesh size was $4.5 \mathrm{~cm}$ and the net height was 33 mesh drops. Soak times for both longlines and gillnets averaged approximately $1 \mathrm{~h}$. All captured shark and teleost species were identified, measured (total length: nose to tip of the upper lobe of the caudal fin), sexed, sampled for SIA (muscle and blood), tagged and released.

\section{Stable isotope tissue sampling, preparation and analysis}

The tissues examined for SIA in this study were muscle, blood plasma, and red blood cells. These tissues were selected based on differences in their turnover rates which represent a broad feeding time scale (estimated time to $95 \%$ diet equilibrium for muscle and blood is 422 and $265 \mathrm{~d}$, respectively; MacNeil et al. 2006), their comparability with other studies, and ease of collection using minor invasive methods. Muscle tissue was extracted from just behind the first dorsal fin in sharks, and immediately adjacent to the dorsal fin in teleosts using a $4 \mathrm{~mm}$ disposable biopsy punch. Blood was taken from the caudal vein just anterior to the tail in both sharks and teleosts using a heparinized needle and syringe. After collection blood samples were spun in a portable centrifuge in the field for approximately $90 \mathrm{~s}$. Using an Eppendorf automatic 100 to $1000 \mu \mathrm{l}$ pipette the resultant plasma and red blood cell layers were pipetted into individually labelled $3 \mathrm{ml}$ Eppendorf safe-lock microcentrifuge tubes. All samples were stored on ice during transport and immediately frozen $\left(-20^{\circ} \mathrm{C}\right)$ on return to the laboratory.
Tissue samples were collected from sharks and teleosts within a restricted size range. The lower limit for sharks was set at the size when the umbilical scar was completely healed to avoid the effect of maternal influence on stable isotope signatures of young animals (Hussey et al. 2010b, Olin et al. 2011). Maximum sizes for sampled sharks were based on sizes prior to maturity, to include only individuals likely to be using the habitat as a nursery. An exception to this maximum size limit was the Australian sharpnose shark, which attains maturity after $1 \mathrm{yr}$ and remains within nursery habitats throughout its life (Carlson et al. 2008). For this species any captured animals with healed umbilical scars were sampled. Teleost tissue samples were taken from the largest captured individuals of the target species in an effort to only sample individuals that had already shifted to a more piscivorous diet (Baker \& Sheaves 2005). All tissue samples were freeze dried and then ground to a powder using hand-held polypropylene pellet pestles.

Within animal tissues, lipids are reportedly depleted in ${ }^{13} \mathrm{C}$ relative to proteins and carbohydrates (Post et al. 2007). Variations in lipid content among organisms and tissue types can potentially lead to more negative $\delta^{13} \mathrm{C}$ values creating misleading stable isotope results unless corrected (Post et al. 2007). The focus of our study on comparing stable isotope values between sharks and teleosts inhabiting the same coastal environment necessitated the extraction of lipids in order to avoid this potential source of error. All tissues were lipid extracted in the same manner (see below) and results are based on lipid extracted values.

Lipid extraction (LE) was undertaken following a modified Bligh \& Dyer (1959) method. Powdered tissue samples were combined with $5 \mathrm{ml}$ of $2: 1$ chloroform-methanol then placed in a water bath $\left(30^{\circ} \mathrm{C}\right)$ for $24 \mathrm{~h}$. Upon removal from the water bath, LE tissue samples were agitated for $30 \mathrm{~s}$, centrifuged for $3 \mathrm{~min}$ (15000 rpm), and then decanted. A second measure of $5 \mathrm{ml}$ of 2:1 chloroform-methanol was then added followed by another round of agitating and centrifuging before the final decant. The resulting tissue pellet was left to dry overnight in a fume hood. Once dry, between 400 and $600 \mu \mathrm{g}$ of the powered LE tissue sample was weighed out into tin capsules and both stable carbon and nitrogen isotope ratios and total percent carbon and percent nitrogen were determined by a continuous flow isotope ratio mass spectrometer (Finnigan MAT Delta ${ }^{\text {plus }}$ ) equipped with an elemental analyzer (Costech). Due to low percent carbon and nitrogen encountered when using LE 
plasma (B. McMeans pers. comm.), 1000 to $1200 \mu \mathrm{g}$ of LE plasma samples were used.

Stable isotope ratios are expressed in $\delta$ notation as deviations from standards in parts per thousand (\%o) according to the following:

$$
\delta X=\left[\left(R_{\text {sample }} / R_{\text {standard }}\right)-1\right] \times 1000
$$

where $X$ is ${ }^{13} \mathrm{C}$ or ${ }^{15} \mathrm{~N}, R_{\text {sample }}$ is the corresponding ratio of ${ }^{13} \mathrm{C} /{ }^{12} \mathrm{C}$ or ${ }^{15} \mathrm{~N} /{ }^{14} \mathrm{~N}$ and $R_{\text {standard }}$ represents the ratio of the respective standard. The standard reference material was Pee Dee Belemnite carbonate for $\mathrm{CO}_{2}$ and atmospheric nitrogen for $\mathrm{N}_{2}$. Replicate analyses of National Institute of Standards and Technology (NIST) standard bovine muscle (NIST 8414, $\mathrm{n}=67$ ) and an internal lab standard (Tilapia Oreochromis niloticus muscle, $\mathrm{n}=67$ ) yielded, respectively, a precision (i.e. $1 \mathrm{SD}$ ) of $0.15 \%$ and 0.24 for $\delta^{15} \mathrm{~N}$ and $0.06 \%$ and $0.09 \%$ for $\delta^{13} \mathrm{C}$.

\section{Stomach content collection and analysis}

Concurrent to the fisheries-independent sampling for stable isotopes a number of fisheries-dependent observer trips were conducted to gather stomach content data from sharks captured aboard commercial fishing boats operating in the Queensland inshore gillnet fishery. Stomach contents were used to validate stable isotope findings and reinforce assessments of generalist or specialist feeding strategies identified via variations in mean isotopic values. Stomach contents were removed from landed sharks and stored frozen for transportation. In the laboratory, stomach contents were washed over a sieve, identified to the lowest possible taxonomic level, counted, weighted, assessed for digestive state (classified as 0 to 4 , with higher numbers indicating a more digested state), and total length measured to the nearest millimeter. Diet composition was analyzed using the percent index of relative importance (\%IRI) (Pinkas et al. 1971), which combines 3 quantitative measurements: percent frequency of occurrence $\left(\% F_{\mathrm{o}}\right)$, percent number counted $\left(\% N_{\mathrm{c}}\right)$ and percent weight $\left(\% W_{\mathrm{c}}\right)$.

$$
\% \text { IRI }=\left(\% N_{\mathrm{c}}+\% W_{\mathrm{c}}\right) \times \% F_{\mathrm{o}}
$$

By expressing IRI values as a percentage (\%IRI), values between individual prey groups are standardized (Cortés 1997).\%IRI values were compared to SIA data to confirm conclusions derived from the nursery assemblage stable isotope profiles.

\section{Statistical analysis}

Least squares linear regressions were used to assess the effect of increasing shark body size on $\delta^{15} \mathrm{~N}$ and $\delta^{13} \mathrm{C}$ values to ensure that body size was not the driving force behind species-specific variations in stable isotope values. For $\delta^{13} \mathrm{C}$ and $\delta^{15} \mathrm{~N}$ values, isotope bi-plots were graphed for all 10 species ( 7 shark and 3 teleost) to show the range of values displayed within the Cleveland Bay community. Data was normally distributed and so a factorial multivariate analysis of variance (MANOVA) was used to asses if the differences between species and sample tissue types were significant, and univariate analysis was used to test if differences were significant for either carbon or nitrogen separately across all examined species and tissue types. A post-hoc Tukey's honestly significant difference (HSD) test for homogenous groups was undertaken to establish groupings of species which showed statistically significantly different carbon or nitrogen values (Cherel et al. 2008).

\section{RESULTS}

Over 300 tissue samples were collected and analyzed for stable isotopes from 101 captured individuals (69 sharks, 32 teleosts), across 10 species. Capture locations ranged across Cleveland Bay and, except for barramundi Lates calcarifer (Bloch, 1790), examined species were not found exclusively in any one area. Least squares linear regressions found that $\delta^{15} \mathrm{~N}$ and $\delta^{13} \mathrm{C}$ values did not vary systematically with total length for any of the 7 sampled shark species (Table 2), demonstrating that there was no confounding species-specific effect of size on $\delta^{15} \mathrm{~N}$ or $\delta^{13} \mathrm{C}$ values. Data from tag recapture and fisheries independent catch (M. J. Kinney unpubl. data), as well as passive acoustic monitoring (C. A. Simpfendorfer unpubl. data), collected concurrent to stable isotope samples, identified patterns of continued residency in Cleveland Bay during early life stages of examined species. Each species was therefore considered as a homogeneous group with tissue stable isotope values representative of their diet in the nursery habitat of Cleveland Bay.

\section{Stable isotope values}

Average $\delta^{13} \mathrm{C}$ values spanned a wide range (-13.3 to $-17.1 \%$ ) across predator species of Cleveland Bay 
Table 2. Results of linear regressions examining the effect of size of sharks on $\delta^{15} \mathrm{~N}$ and $\delta^{13} \mathrm{C}$ values in muscle, plasma and red blood cells

\begin{tabular}{|c|c|c|c|c|c|c|}
\hline \multirow{2}{*}{ Species } & \multicolumn{3}{|c|}{$-\delta^{15} \mathrm{~N}$} & \multicolumn{3}{|c|}{$\delta^{13} \mathrm{C}$} \\
\hline & $\mathrm{r}$ & $\mathrm{p}$ & Slope & $\mathrm{r}$ & $\mathrm{p}$ & Slope \\
\hline \multicolumn{7}{|l|}{ Muscle } \\
\hline Australian sharpnose shark & 0.468 & 0.204 & 0.010 & -0.099 & 0.818 & -0.003 \\
\hline Creek whaler shark & 0.336 & 0.416 & 0.001 & -0.353 & 0.391 & -0.001 \\
\hline Hardnose shark & -0.335 & 0.345 & -0.002 & -0.577 & 0.333 & -0.003 \\
\hline Milk shark & -0.586 & 0.097 & -0.002 & 0.613 & 0.079 & 0.005 \\
\hline Pigeye shark & -0.629 & 0.051 & -0.002 & 0.358 & 0.31 & 0.003 \\
\hline Spottail shark & 0.606 & 0.063 & 0.003 & 0.373 & 0.289 & 0.005 \\
\hline Blacktip shark & -0.484 & 0.132 & -0.003 & -0.028 & 0.934 & 0.000 \\
\hline \multicolumn{7}{|l|}{ Plasma } \\
\hline Australian sharpnose shark & 0.086 & 0.801 & 0.001 & -0.004 & 0.991 & 0.000 \\
\hline Creek whaler shark & 0.438 & 0.238 & 0.001 & 0.178 & 0.648 & 0.001 \\
\hline Hardnose shark & -0.615 & 0.058 & -0.003 & 0.634 & 0.067 & 0.010 \\
\hline Milk shark & -0.230 & 0.552 & -0.001 & -0.319 & 0.403 & -0.002 \\
\hline Pigeye shark & -0.259 & 0.471 & -0.001 & 0.512 & 0.130 & 0.003 \\
\hline Spottail shark & 0.481 & 0.159 & 0.002 & 0.288 & 0.453 & 0.002 \\
\hline Blacktip shark & -0.549 & 0.080 & -0.003 & 0.062 & 0.855 & 0.000 \\
\hline \multicolumn{7}{|l|}{ Red blood cells } \\
\hline Australian sharpnose shark & 0.165 & 0.628 & 0.002 & -0.242 & 0.474 & -0.001 \\
\hline Creek whaler shark & 0.359 & 0.342 & 0.001 & 0.059 & 0.88 & 0.000 \\
\hline Hardnose shark & -0.390 & 0.265 & -0.002 & -0.526 & 0.119 & -0.003 \\
\hline Milk shark & 0.268 & 0.486 & 0.001 & -0.175 & 0.653 & -0.001 \\
\hline Pigeye shark & -0.209 & 0.563 & 0.000 & 0.192 & 0.594 & 0.001 \\
\hline Spottail shark & 0.050 & 0.897 & 0.000 & 0.489 & 0.266 & 0.007 \\
\hline Blacktip shark & -0.383 & 0.245 & -0.001 & -0.150 & 0.66 & -0.001 \\
\hline
\end{tabular}

(Fig. 1, Table A1 in the Appendix), indicating a broad prey base supported by a number of carbon sources. Variance of $\delta^{13} \mathrm{C}$ means for individual species was diverse and varied by tissue type. Some species displayed high variance across multiple tissue types, such as pigeye Carcharhinus amboinensis (Müller \& Henle, 1839) and blacktip sharks Carcharhinus limbatus/tilstoni (Müller \& Henle, 1839)/(Whitley, 1950), while other species, such as the Australian sharpnose shark Rhizoprionodon taylori (Ogilby, 1915), showed minimal variance (Fig. 1, Table A1). Species with highly variant carbon values were likely feeding on multiple carbon sources while species with tighter carbon values most likely specialize on a smaller number of prey items (Layman et al. 2007, Newsome et al. 2009).

Values of $\delta^{15} \mathrm{~N}$ had a smaller range of average species values than $\delta^{13} \mathrm{C}$ for all tissue types examined (from 10.3 to $13.7 \%$ ) (Fig. 1, Table A1), indicating that species in the bay were feeding on a wide range of prey species which likely occupy a similar trophic position with similar $\delta^{15} \mathrm{~N}$ values. Variance in $\delta^{15} \mathrm{~N}$ values for all tissue types was highest for barramundi Lates calcarifer (Bloch, 1790), while spottail shark Carcharhinus sorrah (Müller \& Henle, 1839) and school mackerel Scomberomorus queenslandicus (Munro, 1943) showed the least variance (Fig. 1, Table A1). Similar to carbon, highly variant nitrogen isotope values indicated that a species diet was more diverse than a species with a less varied value.

All 7 sympatric shark species and 3 predatory teleost species from Cleveland Bay showed statistically significant differences in their overall isotopic values (MANOVA, Wilks' lambda, $F_{18,542}=21.65, \mathrm{p}<$ $0.0001)$, as did all tissue types $\left(F_{4,542}=59.79, \mathrm{p}<\right.$ 0.0001). In univariate analyses, both $\delta^{13} \mathrm{C}\left(F_{9,272}=\right.$ $22.11, \mathrm{p}<0.0001)$ and $\delta^{15} \mathrm{~N}\left(F_{9,272}=17.60, \mathrm{p}<0.0001\right)$ values were significantly different between all examined species, as were $\delta^{13} \mathrm{C}\left(F_{2,272}=19.59, \mathrm{p}<0.0001\right)$ and $\delta^{15} \mathrm{~N}\left(F_{2,272}=83.10, \mathrm{p}<0.0001\right)$ values for all tissue types.

Post-hoc Tukey's HSD test for homogenous groups broke the 10 species into 5 groups for $\delta^{13} \mathrm{C}$ means, and 3 groups for $\delta^{15} \mathrm{~N}$ means (Table 3). The $\delta^{13} \mathrm{C}$ groups showed some overlap, which was to be expected considering the observed range of $\delta^{13} \mathrm{C}$ standard deviations (Table 3a). School mackerel and barramundi formed the smallest group (Table 3a: Group 5). Overlap in the remaining 4 groups was largely attributed to 2 species, creek whalers Carcha- 

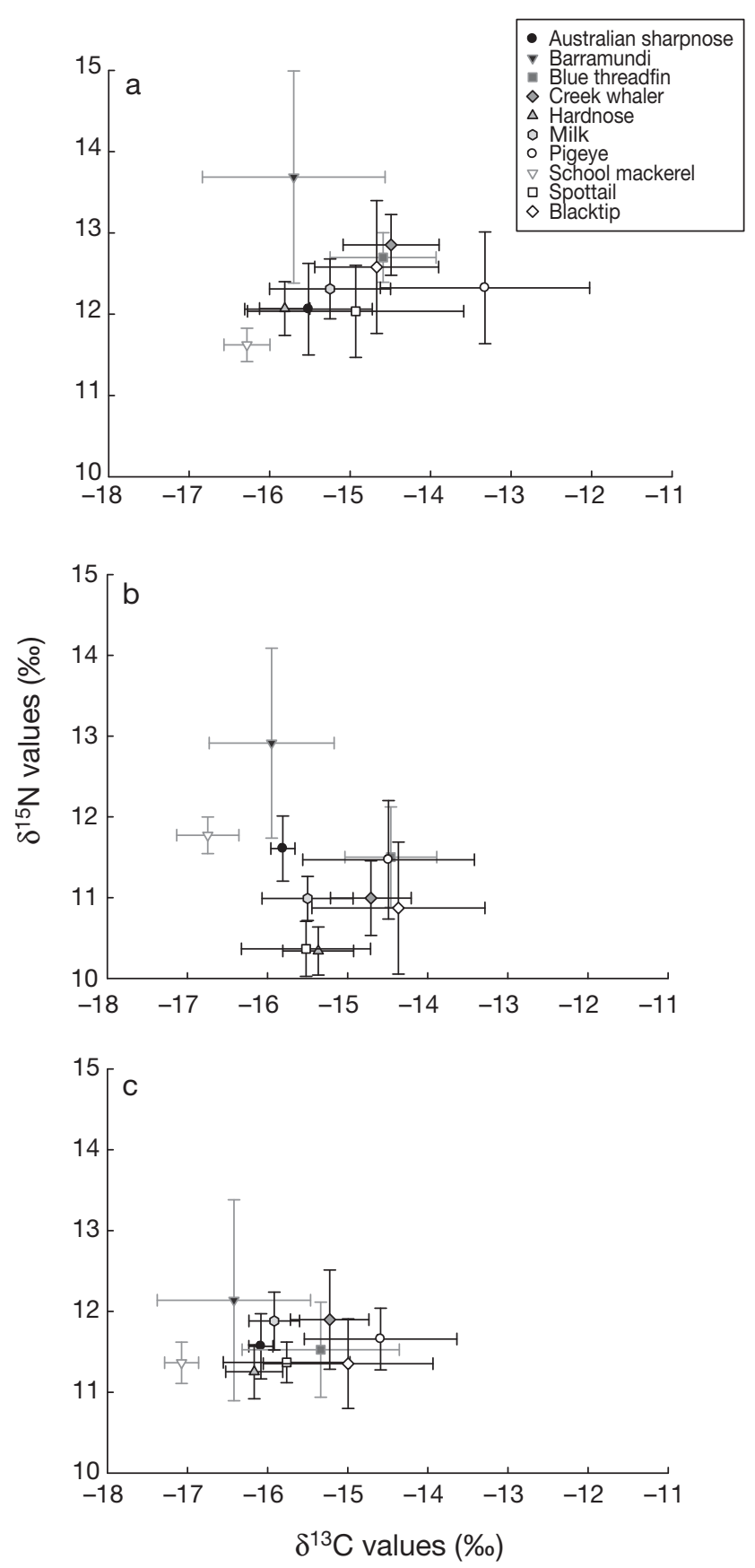

Fig. 1. Mean $( \pm \mathrm{SD}) \delta^{13} \mathrm{C}$ and $\delta^{15} \mathrm{~N}$ values for all species of sharks and teleosts in (a) muscle, (b) plasma and (c) red blood cells. Symbols with gray lines indicate teleost species

rhinus fitzroyensis (Whitley, 1943) and spottail sharks, which displayed broad $\delta^{13} \mathrm{C}$ values. This indicated that the diet of these 2 species was more generalized, allowing them to bridge 3 of the 4 remaining groups. Barramundi, and Australian sharpnose, hardnose C. macloti (Müller \& Henle, 1839) and milk sharks Rhizoprionodon acutus (Rüppell, 1837) formed one group (Table 3a: Group 1), while blue threadfin Eleutheronema tetradactylum (Shaw, 1804), and blacktip and pigeye sharks formed another (Table 3a: Group 2). The remaining 2 groups were composed of the 2 bridging species (creek whalers and spottail sharks), along with 2 minor bridging species, milk sharks and blue threadfin, whose $\delta^{13} \mathrm{C}$ values spanned across 2 groups (Table 3a: Groups 3-4). Of the 3 teleost species, only school mackerel separated completely from the 7 shark species. These post-hoc groups showed that sharks in Cleveland Bay displayed a wide range of $\delta^{13} \mathrm{C}$ values, but within that range there were distinct species assemblages supported by different primary carbon sources, while a few species exploited a wide range of carbon sources.

The post-hoc Tukey's HSD test for homogenous groups of $\delta^{15} \mathrm{~N}$ values separated the 10 species into 3 groups with considerable overlap (Table $3 b$ ). The first group contained all shark species except hardnose and spottail sharks, and all teleost species except barramundi (Table 3b: Group 1). The second group was similar to Group 1 except that it included hardnose and spottail sharks while excluding pigeye shark, creek whalers and blue threadfin (Table 3b: Group 2). The third and final group contained only barramundi (Table 3b: Group 3). These $\delta^{15} \mathrm{~N}$ groupings indicated that the examined species in Cleveland Bay showed a high degree of overlap in $\delta^{15} \mathrm{~N}$ values which was not surprising considering the range of nitrogen values across all species and tissue types was only $3.4 \%$ (Fig. 1), while trophic levels are typically separated by between 2 and $4 \%$.

\section{Index of relative importance profiles}

A total of 742 stomachs were collected and examined from 5 shark species for which we also collected stable isotope samples and that fell within our defined size parameters. The \%IRI calculations revealed a wide array of prey items in the diet of all species; however, some species displayed more specialized diets then others (Table A2 in the Appendix). Milk, spottail and blacktip sharks all displayed broad $\delta^{13} \mathrm{C}$ values and each fed on a wide variety of prey categories $(13,17,12$, respectively; Table A2). In contrast, Australian sharpnose sharks showed little variation in $\delta^{13} \mathrm{C}$ values, and also had a small number of prey categories in the stomach contents (accepting the low sample size for this species), with only 6 identified categories (Table A2). 
Table 3. Results of post-hoc Tukey's honestly significant difference (HSD) test for homogenous groups: (a) shark and teleost species grouped by mean $\delta^{13} \mathrm{C}$ values, indicating the range of exploited carbon sources; (b) shark and teleost species grouped by mean $\delta^{15} \mathrm{~N}$ values, identifying trophic level differences between species. Groupings are based on mean values across all sampled tissue types, Asterisks indicate which group a given species fits into

\begin{tabular}{|c|c|c|c|c|c|c|}
\hline (a) Species & $\delta^{13} \mathrm{C}$ mean & Group 1 & Group 2 & Group 3 & Group 4 & Group 5 \\
\hline School mackerel & -16.7 & & & & & **** \\
\hline Barramundi & -16.0 & $* * * *$ & & & & ${ }^{* * * *}$ \\
\hline Australian sharpnose shark & -15.8 & $* * * *$ & & & & \\
\hline Hardnose shark & -15.6 & $* * * *$ & & & & \\
\hline Milk shark & -15.6 & $* * * *$ & & $* * * *$ & & \\
\hline Spottail shark & -15.4 & $* * * *$ & & $* * * *$ & $* * * *$ & \\
\hline Creek whaler shark & -14.8 & & $* * * *$ & $* * * *$ & $* * * *$ & \\
\hline Blue threadfin & -14.8 & & $* * * *$ & & $* * * *$ & \\
\hline Blacktip shark & -14.7 & & $* * * *$ & & & \\
\hline Pigeye shark & -14.1 & & $* * * *$ & & & \\
\hline (b) Species & $\delta^{15} \mathrm{~N}$ mean & Group 1 & Group 2 & Group 3 & & \\
\hline Hardnose shark & 11.2 & & $* * * *$ & & & \\
\hline Spottail shark & 11.3 & & $* * * *$ & & & \\
\hline Blacktip shark & 11.6 & $* * * *$ & $* * * *$ & & & \\
\hline School mackerel & 11.6 & $* * * *$ & $* * * *$ & & & \\
\hline Milk shark & 11.7 & $* * * *$ & $* * * *$ & & & \\
\hline Australian sharpnose shark & 11.7 & $* * * *$ & $* * * *$ & & & \\
\hline Pigeye shark & 11.8 & **** & & & & \\
\hline Creek whaler & 11.9 & $* * * *$ & & & & \\
\hline Blue threadfin & 11.9 & $* * * *$ & & & & \\
\hline Barramundi & 12.9 & & & $* * * *$ & & \\
\hline
\end{tabular}

\section{DISCUSSION}

The results of our study provide quantitative evidence of dietary resource partitioning among young sharks of several species within a communal nursery area. What was once considered an environment with abundant dietary resources with limited resource partitioning appears instead to be a competition-rich area where young sharks partition resources amongst themselves, as well as other predatory teleost species. Highly clustered $\delta^{15} \mathrm{~N}$ species values indicated that both the juvenile sharks and teleosts in the bay were feeding at similar trophic positions. However, the range of $\delta^{13} \mathrm{C}$ values among species indicated that within that trophic level there were several different source pathways with distinct carbon signatures. Differences in the variance of $\delta^{15} \mathrm{~N}$ and $\delta^{13} \mathrm{C}$ means among species also indicated that certain sharks and teleosts displayed a more generalist diet, while others were more specialized, providing another possible avenue by which dietary resources could be partitioned. The $\delta^{15} \mathrm{~N}$ and $\delta^{13} \mathrm{C}$ values of some teleost species overlapped with the 7 shark species, suggesting that these teleosts are a source of potential competition in addition to the inter- and intra-specific competition among sharks. This added competitive element may make niche partitioning, at least in terms of dietary resources, a more advantageous option for young sharks.

The $\delta^{15} \mathrm{~N}$ values of young sharks in Cleveland Bay were highly clustered, ranging only $\sim 3.6 \%$ across all tissue types (with 2 to $4 \%$ o the difference between trophic levels) indicating that these sharks were all feeding within the same trophic level. The $\delta^{15} \mathrm{~N}$ values of 2 of the sampled predatory teleost species, blue threadfin and school mackerel, displayed overlap in $\delta^{15} \mathrm{~N}$ values with sharks in the bay indicating that these species were likely feeding within the same tropic guild. Only barramundi differed significantly from the examined sharks, displaying an inflated $\delta^{15} \mathrm{~N}$ value which may indicate feeding at a higher trophic level, or may simply be a reflection of the lower diet tissue discrimination factor of sharks (2.3\%, Hussey et al. 2010a) compared to teleosts $(3.0 \%$, Vanderklift \& Ponsard 2003 ; or $\sim 2.5 \%$, Caut et al. 2009). A further explanation for the enriched $\delta^{15} \mathrm{~N}$ values of the barramundi could be due to a unique feature of their capture location. All sampled barramundi were captured on the sand flats adjacent to the discharge point of a tertiary treated sewage pipe at the southern end of the bay. Barramundi found on the flats display little movement out of the area based on findings from tracking work (A. Maplestone pers. comm.). The enrichment of 
localized food sources and the limited movements displayed by barramundi in the area likely result in the observed high $\delta^{15} \mathrm{~N}$ values for this species (Schlacher et al. 2005). Apart from barramundi, few sharks were captured near this discharge point despite extensive fishing efforts in the area, and none were found to reside in the area over extended periods (M. J. Kinney unpubl. data).

Tukey's HSD test for homogenous groups separated the examined species into only 3 groups based on $\delta^{15} \mathrm{~N}$ values. The overlap between these groups was extensive, with barramundi the only species that displayed significantly different values. Based on $\delta^{15} \mathrm{~N}$ values alone, the dietary overlap of juvenile sharks and predatory teleosts may be high in communal shark nursery areas such as Cleveland Bay. Stable isotope studies on coexisting teleost species have found similar results with $\delta^{15} \mathrm{~N}$ values indicating feeding within a single trophic level (Thomas \& Cahoon 1993, Paterson \& Drouillard 2006). These results also agree with the prevailing communal nursery area research that suggests high dietary overlap among sharks based on stomach content analysis (Castro 1993, Simpfendorfer \& Milward 1993).

The $\delta^{13} \mathrm{C}$ values of the sharks and teleosts covered a similar range to $\delta^{15} \mathrm{~N}$ of $\sim 3.8 \%$ across all tissue types, but because $\delta^{13} \mathrm{C}$ has a smaller diet tissue discrimination value, $\delta^{13} \mathrm{C}$ results indicate several primary carbon sources were exploited by the study species. Three of the 5 groups identified by the posthoc Tukey's HSD test for homogenous groups displayed minimal overlap while the remaining 2 groups contained species whose values bridged different groups. The broad range of $\delta^{13} \mathrm{C}$ values displayed across all species, as well as the 5 groups identified in the Tukey's test, provide strong evidence in favour of a nursery environment that is partitioned in terms of basal dietary resources. This is in agreement with stable isotope studies on coexisting teleost species which found similar $\delta^{15} \mathrm{~N}$ values, but variable $\delta^{13} \mathrm{C}$ values which were attributed to resource partitioning between species occupying similar trophic positions in the same habitat (Nagelkerken \& van der Velde 2004, Paterson \& Drouillard 2006). Thomas \& Cahoon (1993) investigated 5 species of reef-associated teleosts and found that while each of the species seemed to occupy the same trophic position, their $\delta^{13} \mathrm{C}$ values indicated at least 2 supporting trophic pathways, one planktonic and the other benthic.

Our results, indicating a wide range of $\delta^{13} \mathrm{C}$ values among our study species, conflict with the estab- lished communal shark nursery area paradigm (Simpfendorfer \& Milward 1993). Instead of an environment where resource partitioning is limited due to abundant resources, our findings indicated that young sharks in communal nursery areas partition the resources of the area amongst themselves as well as other predatory species such as large teleosts. This suggests that food resources may not be as abundant as was once thought and that resource partitioning is a strategy employed to reduce competition. Our findings, along with other recent research on communal shark nursery areas, such as Bethea et al. (2004), who similarly suggest that juvenile sharks within nursery areas may be partitioning resources on both temporal and spatial scales, further strengthen the claim that the prevailing shark nursery area paradigm whether applied to single species or communal shark nursery areas - is outdated and no longer fits much of the current data.

The variance in $\delta^{13} \mathrm{C}$ values displayed by some species possibly indicates another approach to dietary niche separation employed by sharks and teleosts in Cleveland Bay. Species which had greater variance in their $\delta^{13} \mathrm{C}$ values, such as barramundi, and milk, spottail, pigeye, and blacktip sharks, are potentially feeding on a wide variety of prey species, typifying a more generalist diet (see Wetherbee et al. 1990 for a review of shark feeding strategies). This feeding strategy enables these species to exploit a variety of food sources opportunistically. Alternatively, species such as the school mackerel, and Australian sharpnose, and hardnose sharks exhibited lower variation in $\delta^{13} \mathrm{C}$ values, indicating that these species were likely feeding on a more specialized diet. This may allow them to avoid or reduce competitive interactions by specializing on a small number of prey species that can be exploited more successfully than by their potential competitors (Mihuc 1997), or by focusing on more abundant prey species for which competition is lower, or it may be as a result of being outcompeted, necessitating feeding on non-preferred prey items (Baird et al. 1992). However, caution is warranted when using variation around stable isotope means as a measure of generalist versus specialist feeding strategies. Although, the potential of this method has been discussed (Bearhop et al. 2004), variation in consumers' stable isotope values could be driven by variation at the prey level. We used stomach contents to deal with this issue, which is discussed below.

Values of \%IRI serve to validate the division of examined sharks into these groups by providing a quantitative number of prey groups for each species. 
Groups of generalist and specialist species identified by the 2 methods agree well for all species except pigeye shark. Pigeye sharks exhibit greater than average variation in $\delta^{13} \mathrm{C}$ values among examined shark species; however, stomach content analysis revealed only 6 prey categories (accepting the low sample size for this species), about half the number of categories found in other species classified as generalists (milk, spottail and blacktip sharks) (Table A2). Only when examined more closely do these findings reveal the nature of the pigeyes' diet. In contrast to the other shark species which typically feed on relatively similar prey items (teleosts from families including Clupeidae, Mullidae and Leiognathidae), pigeyes feed on a wide range of prey, including teleost (Engraulidae and Polynemidae), sea snakes (Hydrophiidae) and other sharks (Carcharhinidae). These prey may occupy similar trophic positions during certain periods of their lives but are likely supported by different primary carbon sources. In essence, pigeye sharks exhibit a generalist $\delta^{13} \mathrm{C}$ signature but are actually feeding on relatively few prey items that are isotopically dissimilar, making it more likely that this species is a specialist predator despite its varied $\delta^{13} \mathrm{C}$ values. It would be easy to assume that with highly varied $\delta^{13} \mathrm{C}$ values a species is likely feeding on a number of prey items and is probably a generalist. However, as shown, this 1-dimensional approach can be misleading and it is important to validate stable isotope results whenever possible with stomach content data.

Despite the utility of our SIA approach to questions of shark nursery area feeding strategies, this method does have a limitation. The persistence of stable isotope values from adult females in their young precludes the sampling of neonates, preventing the exploration of dietary resource partitioning among the youngest animals in the nursery. However, feeding success in these neonate sharks is generally low, as demonstrated by measured weight loss in young sharks (Duncan \& Holland 2006) attributed to the utilization of parental reserves stored in their livers (Hussey et al. 2010b). This would mean that results gathered from neonate animals would be unlikely to reveal dietary resource strategies which relate to competition or resource partition in the nursery.

\section{CONCLUSION}

Stable isotope analysis is a powerful tool that can greatly improve our understanding of ecological communities. Through comparing the stable isotope values of multiple tissues within variable integration periods from multiple shark and teleost species within a known communal shark nursery, we were able to elucidate important information on species resource partitioning strategies. Understanding how different species utilize the dietary resources within important habitats such as nursery areas is a key component in identifying how best to manage and protect these areas (Heithaus 2005).

Nursery area management, if implemented properly (Heupel et al. 2007, Kinney \& Simpfendorfer 2009), has the potential to be a powerful tool for shark conservation. Future investigations into nursery areas that incorporate SIA could provide more detailed knowledge about inter- and intra-species resource use which is often missing from current management efforts. Coupling this technique with investigations of other resource use strategies within a nursery, such as temporal or spatial habitat usage, could greatly improve our understanding and ability to mange these environments. This knowledge would be particularly valuable to inform management of communal nursery areas in order to provide strategic protection for multiple co-occurring shark species while avoiding the need to protect vast coastal stretches.

Acknowledgements. This research was supported by funding from the Marine and Tropical Sciences Research Facility (MTSRF), James Cook University (JCU), and the School for Earth and Environmental Sciences (SEES). We thank Cynthia Awruch, Al Harry, Amos Maplestone, and the countless volunteers whose assistance in the field made this research possible, as well as Dr. Jennifer Elliman for her assistance in processing samples. We also thank all of the commercial fishermen who facilitated the collection of stomach contents by allowing observers onto their vessels. Finally, we thank the staff at the Great Lakes Institute for Environmental Science for their hospitality and for sharing their invaluable expertise in stable isotope analysis.

\section{LITERATURE CITED}

Baird RW, Abrams PA, Dill LM (1992) Possible indirect interactions between transient and resident killer whales: implications for the evolution of foraging specializations in the genus Orcinus. Oecologia 89:125-132

Baker R, Sheaves M (2005) Redefining the piscivore assemblage of shallow estuarine nursery habitats. Mar Ecol Prog Ser 291:197-213

> Bearhop S, Adams CE, Waldron S, Fuller RA, Macleod H (2004) Determining trophic niche width: a novel approach using stable isotope analysis. J Anim Ecol 73: 1007-1012

Bethea DM, Buckel JA, Carlson JK (2004) Foraging ecology of the early life stages of four sympatric shark species. Mar Ecol Prog Ser 268:245-264

Bligh EG, Dyer WJ (1959) A rapid method of total lipid 
extraction and purification. Can J Biochem Physiol 37: 911-917

Branstetter S (1990) Early life history implications of selected carcharhinoid and lamnoid sharks of the northwest Atlantic. NOAA Tech Rep NMFS 90:17-24

Bush A, Holland K (2002) Food limitation in a nursery area: estimates of daily ration in juvenile scalloped hammerheads, Sphyrna lewini (Griffith and Smith, 1834) in Kane'ohe Bay, O'ahu, Hawai'i. J Exp Mar Biol Ecol 278: 157-178

Carlson JK, Heupel MR, Bethea DM, Hollensead LD (2008) Coastal habitat use and residency of juvenile Atlantic sharpnose sharks (Rhizoprionodon terraenovae). Estuaries Coasts 31:931-940

> Castro JI (1993) The shark nursery of Bulls Bay, SouthCarolina, with a review of the shark nurseries of the southeastern coast of the United States. Environ Biol Fishes 38:37-48

Caut S, Angulo E, Courchamp F (2009) Variation in discrimination factors $\left(\Delta^{15} \mathrm{~N}\right.$ and $\left.\Delta^{13} \mathrm{C}\right)$ : the effect of diet isotopic values and applications for diet reconstruction. J Appl Ecol 46:443-453

> Cherel Y, Le Corre M, Jaquemet S, Menard F, Richard P, Weimerskirch $H$ (2008) Resource partitioning within a tropical seabird community: new information from stable isotopes. Mar Ecol Prog Ser 366:281-291

Cortés E (1997) A critical review of methods of studying fish feeding based on analysis of stomach contents: application to elasmobranch fishes. Can J Fish Aquat Sci 54:726-738

Cortés E (1999) Standardized diet compositions and trophic levels of sharks. ICES J Mar Sci 56:707-717

Cruz-Motta JJ, Collins J (2004) Impacts of dredged material disposal on a tropical soft-bottom benthic assemblage. Mar Pollut Bull 48:270-280

Cunjak RA, Roussel JM, Gray MA, Dietrich JP, Cartwright DF, Munkittrick KR, Jardine TD (2005) Using stable isotope analysis with telemetry or mark-recapture data to identify fish movement and foraging. Oecologia 144: 636-646

> Das K, Lepoint G, Loizeau V, Debacker V, Dauby $\mathrm{P}$, Bouquegneau JM (2000) Tuna and dolphin associations in the north-east Atlantic: evidence of different ecological niches from stable isotope and heavy metal measurements. Mar Pollut Bull 40:102-109

> DeNiro MJ, Epstein S (1978) Influence of diet on the distribution of carbon isotopes in animals. Geochim Cosmochim Acta 42:495-506

> DeNiro MJ, Epstein S (1981) Influence of diet on the distribution of nitrogen isotopes in animals. Geochim Cosmochim Acta 45:341-351

$>$ Domi N, Bouquegneau JM, Das K (2005) Feeding ecology of five commercial shark species of the Celtic Sea through stable isotope and trace metal analysis. Mar Environ Res 60:551-569

> Duncan KM, Holland KN (2006) Habitat use, growth rates and dispersal patterns of juvenile scalloped hammerhead sharks Sphyrna lewini in a nursery habitat. Mar Ecol Prog Ser 312:211-221

Estrada JA, Rice AN, Lutcavage ME, Skomal GB (2003) Predicting trophic position in sharks of the north-west Atlantic Ocean using stable isotope analysis. J Mar Biol Assoc UK 83:1347-1350

Estrada JA, Lutcavage M, Thorrold SR (2005) Diet and trophic position of Atlantic bluefin tuna (Thunnus thynnus) inferred from stable carbon and nitrogen isotope analysis. Mar Biol 147:37-45

- Estrada JA, Rice AN, Natanson LJ, Skomal GB (2006) Use of isotopic analysis of vertebrae in reconstructiong ontogenetic feeding ecology in white sharks. Ecology 87: 829-834

Fisk AT, Tittlemier SA, Pranschke JL, Norstrom RJ (2002) Using anthropogenic contaminants and stable isotopes to assess the feeding ecology of Greenland sharks. Ecology 83:2162-2172

Grech A, Coles R (2010) An ecosystem-scale predictive model of coastal seagrass distribution. Aquat Conserv 20: $437-444$

> Harvey CJ, Hanson PC, Essington TE, Brown PB, Kitchell JF (2002) Using bioenergetics models to predict stable isotope ratios in fishes. Can J Fish Aquat Sci 59:115-124

Heithaus MR (2005) Nursery areas as essential shark habitats: a theoretical perspective. In: McCandless CT, Kohler NE, Pratt HL (eds) Shark nursery grounds of the Gulf of Mexico and east coast waters of the United States. American Fisheries Society Symposium, Bethesda, MD, p 3-13

> Heupel MR, Simpfendorfer CA (2002) Estimation of mortality of juvenile blacktip sharks, Carcharhinus limbatus, within a nursery area using telemetry data. Can J Fish Aquat Sci 59:624-632

> Heupel MR, Simpfendorfer CA (2010) Science or slaughter: need for lethal sampling of sharks. Conserv Biol 24: 1212-1218

Heupel MR, Carlson JK, Simpfendorfer CA (2007) Shark nursery areas: concepts, definition, characterization and assumptions. Mar Ecol Prog Ser 337:287-297

Hobson KA, Welch HE (1992) Determination of trophic relationships within a high Arctic marine food web using $\delta^{13} \mathrm{C}$ and $\delta^{15} \mathrm{~N}$ analysis. Mar Ecol Prog Ser 84:9-18

Hobson KA, Ambrose WG Jr, Renaud PE (1995) Sources of primary production, benthic-pelagic coupling, and trophic relationships within the Northeast Water Polynya: insights from $\delta^{13} \mathrm{C}$ and $\delta^{15} \mathrm{~N}$ analysis. Mar Ecol Prog Ser 128:1-10

Hobson KA, Fisk A, Karnovsky N, Holst M, Gagnon JM, Fortier M (2002) A stable isotope $\left(\delta^{13} \mathrm{C}, \delta^{15} \mathrm{~N}\right)$ model for the North Water food web: implications for evaluating trophodynamics and the flow of energy and contaminants. Deep-Sea Res II 49:5131-5150

Hussey NE, Brush J, McCarthy ID, Fisk AT (2010a) $\delta^{15} \mathrm{~N}$ and $\delta^{13} \mathrm{C}$ diet-tissue discrimination factors for large sharks under semi-controlled conditions. Comp Biochem Physiol Part A Mol Integr Physiol 155:445-453

Hussey NE, Wintner SP, Dudley SFJ, Cliff G, Cocks DT, Aaron MacNeil M (2010b) Maternal investment and sizespecific reproductive output in carcharhinid sharks. J Anim Ecol 79:184-193

Kerr L, Andrews A, Cailliet G, Brown T, Coale K (2006) Investigations of $\Delta 14 \mathrm{C}, \delta^{13} \mathrm{C}$, and $\delta^{15} \mathrm{~N}$ in vertebrae of white shark (Carcharodon carcharias) from the eastern North Pacific Ocean. Environ Biol Fishes 77:337-353

Kinney MJ, Simpfendorfer CA (2009) Reassessing the value of nursery areas to shark conservation and management. Conserv Lett 2:53-60

- Kurle CM, Worthy GAJ (2002) Stable nitrogen and carbon isotope ratios in multiple tissues of the northern fur seal Callorhinus ursinus: implications for dietary and migratory reconstructions. Mar Ecol Prog Ser 236:289-300

Layman CA, Quattrochi JP, Peyer CM, Allgeier JE (2007) Niche width collapse in a resilient top predator following 
ecosystem fragmentation. Ecol Lett 10:937-944

Logan J, Lutcavage M (2010) Stable isotope dynamics in elasmobranch fishes. Hydrobiologia 644:231-244

Lowe CG (2002) Bioenergetics of free-ranging juvenile scalloped hammerhead sharks (Sphyrna lewini) in Kane'ohe Bay, O'ahu, HI. J Exp Mar Biol Ecol 278:141-156

MacNeil MA, Skomal GB, Fisk AT (2005) Stable isotopes from multiple tissues reveal diet switching in sharks. Mar Ecol Prog Ser 302:199-206

MacNeil MA, Drouillard K, Fisk AT (2006) Variable uptake and elimination of stable nitrogen isotopes between tissues in fish. Can J Fish Aquat Sci 63:345-353

Manire CA, Gruber SH (1993) A preliminary estimate of natural mortality of age-0 lemon sharks, Negaprion brevirostris. NOAA Techn Rep NMFS 115:65-71

McMeans BC, Olin JA, Benz GW (2009) Stable-isotope comparisons between embryos and mothers of a placentatrophic shark species. J Fish Biol 75:2464-2474

Michener RH, Schell DM (1994) Stable isotope ratios as tracers in marine and aquatic food webs. In: Lajtha $\mathrm{K}$, Michener RH (eds) Stable isotopes in ecology and environmental science. Blackwell Scientific Publications, Oxford, p 138-157

Mihuc TB (1997) The functional trophic role of lotic primary consumers: generalist versus specialist strategies. Freshw Biol 37:455-462

> Nagelkerken I, van der Velde G (2004) Relative importance of interlinked mangroves and seagrass beds as feeding habitats for juvenile reef fish on a Caribbean island. Mar Ecol Prog Ser 274:153-159

Newsome SD, Tinker MT, Monson DH, Oftedal OT and others (2009) Using stable isotopes to investigate individual diet specialization in California sea otters (Enhydra lutris nereis). Ecology 90:961-974

Olin JA, Hussey NE, Fritts M, Heupel MR, Simpfendorfer CA, Poulakis GR, Fisk AT (2011) Maternal meddling in neonatal sharks: implications for interpreting stable isotopes in young animals. Rapid Commun Mass Spectrom 25:1008-1016

Paterson G, Drouillard K (2006) Quantifying resources partitioning in centrarchids with stable isotope analysis. Limnol Oceanogr 51:1038-1044

Perga ME, Gerdeaux D (2005) 'Are fish what they eat' all year round? Oecologia 144:598-606

Peterson BJ, Fry B (1987) Stable isotopes in ecosystem studies. Annu Rev Ecol Syst 18:293-320

Pinkas LM, Oliphant S, Iverson ILK (1971) Foot habits of albacore, bluefin tuna and bonito in Californian waters. Calif Fish Game 152:1-105
Pinnegar JK, Polunin NVC (1999) Differential fractionation of $\delta^{13} \mathrm{C}$ and $\delta^{15} \mathrm{~N}$ among fish tissues: implications for the study of trophic interactions. Funct Ecol 13:225-231

Pinnegar JK, Campbell N, Polunin NVC (2001) Unusual stable isotope, fractionation patterns observed for fish host-parasite trophic relationships. J Fish Biol 59:494-503

Platell ME, Potter IC, Clarke KR (1998) Resource partitioning by four species of elasmobranchs (Batoidea: Urolophidae) in coastal waters of temperate Australia. Mar Biol 131:719-734

Post DM (2002) Using stable isotopes to estimate trophic position: models, methods, and assumptions. Ecology 83: 703-718

Post D, Layman C, Arrington D, Takimoto G, Quattrochi J, Montaña C (2007) Getting to the fat of the matter: models, methods and assumptions for dealing with lipids in stable isotope analyses. Oecologia 152:179-189

> Salini JP, Blaber SJM, Brewer DT (1992) Diets of sharks from estuaries and adjacent waters of the north-eastern Gulf of Carpentaria, Australia. Aust J Mar Freshw Res 43: 87-96

> Schlacher TA, Liddell B, Gaston TF, Schlacher-Hoenlinger M (2005) Fish track wastewater pollution to estuaries. Oecologia 144:570-584

Simpfendorfer CA, Milward NE (1993) Utilization of a tropical bay as a nursery area by sharks of the Families Carcharhinidae and Sphyrnidae. Environ Biol Fishes 37: 337-345

Springer S (1967) Social organization of shark populations. In: Gilbert PW, Mathewson RF, Rail DP (eds) Sharks, skates, and rays. John Hopkins University Press, Baltimore, MD, p 149-174

- Thomas CJ, Cahoon LB (1993) Stable isotope analyses differentiate between different trophic pathways supporting rocky-reef fishes. Mar Ecol Prog Ser 95:19-24

Vanderklift MA, Ponsard S (2003) Sources of variation in consumer-diet $\delta^{15} \mathrm{~N}$ enrichment: a meta-analysis. Oecologia 136:169-182

Wetherbee BM, Gruber SH, Cortes E (1990) Diet, feeding habits, digestion, and consumption in sharks, with special reference to the lemon shark, Negaprion brevirostris. NOAA Tech Rep NMFS 90:29-47

White WT, Platell ME, Potter IC (2004) Comparisons between the diets of four abundant species of elasmobranchs in a subtropical embayment: implications for resource partitioning. Mar Biol 144:439-448

Wilson RP, La Cock GD, Wilson MP, Mollagee F (1985) Differential digestion of fish and squid in jackass penguins, Spheniscus demersus. Ornis Scand 16:77-79 
Appendix 1. Summary information for stable isotope values (A1) as well as stomach contents (A2) for each species

Table A1. Summary of mean $( \pm \mathrm{SD}) \delta^{15} \mathrm{~N}, \delta^{13} \mathrm{C}$ and $\mathrm{C}: \mathrm{N}$ values for examined shark and teleost species in Cleveland Bay, QLD, Australia, for all tissue types

\begin{tabular}{|c|c|c|c|c|c|}
\hline Species & Tissue type & $\mathrm{n}$ & $\delta^{13} \mathrm{C}$ & $\delta^{15} \mathrm{~N}$ & $\mathrm{C}: \mathrm{N}$ \\
\hline Australian sharpnose shark & $\begin{array}{c}\text { Muscle } \\
\text { Plasma } \\
\text { Red blood }\end{array}$ & $\begin{array}{l}11 \\
11 \\
11\end{array}$ & $\begin{array}{l}-15.5( \pm 0.8) \\
-15.8( \pm 0.2) \\
-16.1( \pm 0.2)\end{array}$ & $\begin{array}{l}12.1( \pm 0.6) \\
11.6( \pm 0.4) \\
11.6( \pm 0.4)\end{array}$ & $\begin{array}{l}3.3( \pm 0.1) \\
3.8( \pm 0.0) \\
3.4( \pm 0.1)\end{array}$ \\
\hline Barramundi & $\begin{array}{c}\text { Muscle } \\
\text { Plasma } \\
\text { Red blood }\end{array}$ & $\begin{array}{l}11 \\
11 \\
11\end{array}$ & $\begin{array}{l}-15.7( \pm 1.1) \\
-16.0( \pm 0.8) \\
-16.4( \pm 1.0)\end{array}$ & $\begin{array}{l}13.7( \pm 1.3) \\
12.9( \pm 1.2) \\
12.1( \pm 1.2)\end{array}$ & $\begin{array}{l}3.3( \pm 0.1) \\
3.7( \pm 0.1) \\
3.5( \pm 0.3)\end{array}$ \\
\hline Blue threadfin & $\begin{array}{c}\text { Muscle } \\
\text { Plasma } \\
\text { Red blood }\end{array}$ & $\begin{array}{l}11 \\
11 \\
11\end{array}$ & $\begin{array}{l}-14.6( \pm 0.7) \\
-14.5( \pm 0.6) \\
-15.3( \pm 1.0)\end{array}$ & $\begin{array}{l}12.7( \pm 0.3) \\
11.5( \pm 0.6) \\
11.5( \pm 0.6)\end{array}$ & $\begin{array}{l}3.3( \pm 0.1) \\
3.8( \pm 0.1) \\
3.6( \pm 0.2)\end{array}$ \\
\hline Creek whaler shark & $\begin{array}{c}\text { Muscle } \\
\text { Plasma } \\
\text { Red blood }\end{array}$ & $\begin{array}{l}9 \\
9 \\
9\end{array}$ & $\begin{array}{l}-14.5( \pm 0.6) \\
-14.7( \pm 0.5) \\
-15.2( \pm 0.5)\end{array}$ & $\begin{array}{l}12.9( \pm 0.4) \\
11.0( \pm 0.5) \\
11.9( \pm 0.6)\end{array}$ & $\begin{array}{l}3.2( \pm 0.1) \\
3.8( \pm 0.0) \\
3.4( \pm 0.1)\end{array}$ \\
\hline Hardnose shark & $\begin{array}{c}\text { Muscle } \\
\text { Plasma } \\
\text { Red blood }\end{array}$ & $\begin{array}{l}10 \\
10 \\
10\end{array}$ & $\begin{array}{l}-15.8( \pm 0.3) \\
-15.4( \pm 0.4) \\
-16.2( \pm 0.4)\end{array}$ & $\begin{array}{l}12.1( \pm 0.3) \\
10.3( \pm 0.3) \\
11.3( \pm 0.3)\end{array}$ & $\begin{array}{l}3.4( \pm 0.1) \\
3.8( \pm 0.1) \\
3.4( \pm 0.1)\end{array}$ \\
\hline Milk shark & $\begin{array}{c}\text { Muscle } \\
\text { Plasma } \\
\text { Red blood }\end{array}$ & $\begin{array}{l}9 \\
9 \\
9\end{array}$ & $\begin{array}{l}-15.3( \pm 0.8) \\
-15.5( \pm 0.6) \\
-15.9( \pm 0.3)\end{array}$ & $\begin{array}{l}12.3( \pm 0.4) \\
11.0( \pm 0.3) \\
11.9( \pm 0.4)\end{array}$ & $\begin{array}{l}3.2( \pm 0.1) \\
3.8( \pm 0.1) \\
3.4( \pm 0.1)\end{array}$ \\
\hline Pigeye shark & $\begin{array}{c}\text { Muscle } \\
\text { Plasma } \\
\text { Red blood }\end{array}$ & $\begin{array}{l}10 \\
10 \\
10\end{array}$ & $\begin{array}{l}-13.3( \pm 1.3) \\
-14.5( \pm 1.1) \\
-14.6( \pm 1.0)\end{array}$ & $\begin{array}{l}12.3( \pm 0.7) \\
11.5( \pm 0.7) \\
11.7( \pm 0.4)\end{array}$ & $\begin{array}{l}3.2( \pm 0.3) \\
3.7( \pm 0.1) \\
3.4( \pm 0.1)\end{array}$ \\
\hline School mackerel & $\begin{array}{c}\text { Muscle } \\
\text { Plasma } \\
\text { Red blood }\end{array}$ & $\begin{array}{l}10 \\
10 \\
10\end{array}$ & $\begin{array}{l}-16.3( \pm 0.3) \\
-16.8( \pm 0.4) \\
-17.1( \pm 0.2)\end{array}$ & $\begin{array}{l}11.6( \pm 0.2) \\
11.8( \pm 0.2) \\
11.4( \pm 0.3)\end{array}$ & $\begin{array}{l}3.3( \pm 0.1) \\
3.7( \pm 0.1) \\
3.6( \pm 0.1)\end{array}$ \\
\hline Spottail shark & $\begin{array}{c}\text { Muscle } \\
\text { Plasma } \\
\text { Red blood }\end{array}$ & $\begin{array}{l}9 \\
9 \\
9\end{array}$ & $\begin{array}{l}-14.9( \pm 1.3) \\
-15.5( \pm 0.8) \\
-15.8( \pm 0.8)\end{array}$ & $\begin{array}{l}12.0( \pm 0.6) \\
10.4( \pm 0.3) \\
11.4( \pm 0.3)\end{array}$ & $\begin{array}{l}3.3( \pm 0.1) \\
3.8( \pm 0.1) \\
3.5( \pm 0.0)\end{array}$ \\
\hline Blacktip shark & $\begin{array}{c}\text { Muscle } \\
\text { Plasma } \\
\text { Red blood }\end{array}$ & $\begin{array}{l}11 \\
11 \\
11\end{array}$ & $\begin{array}{l}-14.7( \pm 0.8) \\
-14.4( \pm 1.1) \\
-15.0( \pm 1.1)\end{array}$ & $\begin{array}{l}12.6( \pm 0.8) \\
10.9( \pm 0.8) \\
11.4( \pm 0.6)\end{array}$ & $\begin{array}{l}3.4( \pm 0.1) \\
3.7( \pm 0.1) \\
3.5( \pm 0.1)\end{array}$ \\
\hline
\end{tabular}


Table A2. Results of stomach content analysis of commercially caught sharks. Percent number counted (\% $\left.N_{\mathrm{c}}\right)$, percent weight counted $\left(\% W_{\mathrm{c}}\right)$ and percent frequency of occurrence $\left(\% F_{\mathrm{o}}\right)$ values used to calculate index of relative importance values (\%IRI) of prey items

\begin{tabular}{|c|c|c|c|c|c|}
\hline Shark species & Prey items & $\% N_{\mathrm{c}}$ & $\% W_{\mathrm{c}}$ & $\% F_{\mathrm{o}}$ & $\%$ IRI \\
\hline \multirow{6}{*}{ Australian sharpnose shark $(\mathrm{n}=46)$} & Engraulidae (anchovy) & 7.7 & 7.5 & 11.1 & 4.4 \\
\hline & Clupeidae (herring) & 19.2 & 29.5 & 44.4 & 56.3 \\
\hline & Mullidae (goatfish) & 3.8 & 3.7 & 11.1 & 2.2 \\
\hline & Scombridae (mackerel) & 3.8 & 21 & 11.1 & 7.2 \\
\hline & Leiognathidae (ponyfish) & 61.5 & 33.4 & 11.1 & 27.4 \\
\hline & Polynemidae (threadfin) & 3.8 & 4.9 & 11.1 & 2.5 \\
\hline \multirow[t]{13}{*}{ Milk shark $(\mathrm{n}=130)$} & Engraulidae (anchovy) & 1.5 & 0.7 & 2.1 & 0.2 \\
\hline & Clupeidae (herring) & 17.9 & 25.7 & 19.1 & 28.7 \\
\hline & Callionymidae, Draconettidae (dragonet) & 1.5 & 4.1 & 2.1 & 0.4 \\
\hline & Soleidae, Bothidae, etc. (flatfish) & 32.8 & 22.6 & 21.3 & 40.7 \\
\hline & Mullidae (goatfish) & 1.5 & 2.4 & 2.1 & 0.3 \\
\hline & Synodontidae (Saurida) & 1.5 & 0.3 & 2.1 & 0.1 \\
\hline & Scombridae (mackerel) & 1.5 & 15.1 & 2.1 & 1.2 \\
\hline & Mugilidae (mullet) & 1.5 & 3.5 & 2.1 & 0.4 \\
\hline & Leiognathidae (ponyfish) & 13.4 & 7.7 & 14.9 & 10.9 \\
\hline & Penaeidae (prawn) & 14.9 & 5.8 & 17 & 12.2 \\
\hline & Loliginidae (squids) & 6 & 8.3 & 6.4 & 3.2 \\
\hline & Hydrophiidae (sea snake) & 4.5 & 2.1 & 6.4 & 1.5 \\
\hline & Haemulidae (sweetlip) & 1.5 & 1.7 & 2.1 & 0.2 \\
\hline \multirow[t]{6}{*}{ Pigeye shark $(\mathrm{n}=33)$} & Engraulidae (anchovy) & 18.2 & 2.5 & 10 & 5 \\
\hline & Carcharhinidae (shark) & 9.1 & 87.5 & 10 & 23.5 \\
\hline & Crustacea (crab) & 9.1 & 0.4 & 10 & 2.4 \\
\hline & Hydrophiidae (sea snake) & 45.5 & 7.2 & 50 & 64.1 \\
\hline & Polynemidae (threadfin) & 9.1 & 1.5 & 10 & 2.6 \\
\hline & Triacanthidae, Triacanthodidae (tripodfish) & 9.1 & 0.9 & 10 & 2.4 \\
\hline \multirow[t]{17}{*}{ Spottail shark $(n=224)$} & Apogonidae (Apogon) & 0.5 & 0.1 & 0.9 & 0.2 \\
\hline & Gerridae (Gerres) & 4.1 & 7.3 & 3.5 & 2.2 \\
\hline & Clupeidae (herring) & 12.4 & 13.3 & 15.9 & 21.9 \\
\hline & Sciaenidae (croaker and jewfish) & 1.4 & 6.1 & 2.7 & 1.2 \\
\hline & Spirulidae (cuttlefish) & 1.4 & 2.5 & 2.7 & 0.6 \\
\hline & Soleidae, Bothidae, etc. (flatfish) & 0.9 & 0.1 & 1.8 & 0.1 \\
\hline & Terapontidae (striped grunter) & 2.3 & 5.4 & 3.5 & 1.4 \\
\hline & Mullidae (goatfish) & 11.1 & 10.2 & 7.1 & 8.1 \\
\hline & Menidae (moonfish) & 0.9 & 0.9 & 1.8 & 0.2 \\
\hline & Leiognathidae (ponyfish) & 29 & 14.8 & 16.8 & 39.5 \\
\hline & Penaeidae (prawn) & 7.4 & 2.2 & 10.6 & 5.5 \\
\hline & Loliginidae (squids) & 2.8 & 1.8 & 5.3 & 1.3 \\
\hline & Haemulidae (sweetlip) & 12 & 19 & 8.8 & 14.6 \\
\hline & Polynemidae (threadfin) & 1.4 & 3 & 2.7 & 0.6 \\
\hline & Tetraodontidae (toadfish) & 1.4 & 1.1 & 1.8 & 0.2 \\
\hline & Carangidae (trevally) & 2.3 & 0.2 & 1.8 & 1 \\
\hline & Sillaginidae (whiting) & 3.7 & 2.1 & 4.4 & 1.4 \\
\hline \multirow[t]{12}{*}{ Blacktip shark $(n=309)$} & Engraulidae (anchovy) & 0.8 & 0.3 & 1.5 & 0.1 \\
\hline & Gerridae (Gerres) & 1.6 & 4.6 & 3.1 & 0.8 \\
\hline & Ariidae (catfish) & 2.5 & 0.4 & 4.6 & 0.5 \\
\hline & Clupeidae (herring) & 27.9 & 21 & 23.1 & 45.1 \\
\hline & Mullidae (goatfish) & 5.7 & 2.8 & 3.1 & 1.1 \\
\hline & Synodontidae (Saurida) & 1.6 & 7 & 3.1 & 1.1 \\
\hline & Scombridae (mackerel) & 4.1 & 12.5 & 6.2 & 4.1 \\
\hline & Leiognathidae (ponyfish) & 18 & 6 & 10.8 & 10.4 \\
\hline & Penaeidae (prawn) & 2.5 & 1.7 & 4.6 & 0.8 \\
\hline & Loliginidae (squids) & 21.3 & 19.5 & 15.4 & 25.1 \\
\hline & Polynemidae (threadfin) & 7.4 & 10.8 & 12.3 & 8.9 \\
\hline & Carangidae (trevally) & 1.6 & 9.1 & 3.1 & 1.7 \\
\hline
\end{tabular}

